ROCZNIKI HUMANISTYCZNE

Volume 66, issue $1-2018$

SELECTED PAPERS IN ENGLISH

DOI: http://dx.doi.org/10.18290/rh.2018.66.1-8e

\title{
MATEUSZ ANTONIUK
}

\section{INTERPRETATION AS FEELING SETTLED \\ A FEW THOUGHTS ABOUT READING (POEMS)}

1.

What does interpretation of a literary text mean to me? Why and how do I want to deal with it? What do I try to achieve with it? What makes me most curious about interpretation? What gives me pleasure, what discourages me and makes me tired? The invitation to submit an article to Roczniki Humanistyczne devoted to the issues of interpretation is also an invitation to address the above group of questions and reflections. If I were to find now, in the first paragraph, a single, concise formula that captures what I think about the interpretative activities, I would say most willingly: feeling at home in the text. Interpretation can be done as an attempt to get settled in the text. At least I hope so, I think so, and I would like to justify this thinking in my article. First things first, though.

2.

Let me refer to a Czesław Miłosz poem, which debuted in print in the $\mathrm{Pa}$ risian Kultura in 1967, and two years later was included in the City Without a Name (Miasto bez imienia) poetry volume:

Dr hab. Mateusz Antoniuk - assistant professor at the Faculty of Polish Studies of the Jagiellonian University in Krakow; address for correspondence: e-mail: antoniuk2@interia.pl

The Polish version of the article was published in Roczniki Humanistyczne vol. 59, issue 1, (2011). 


\section{WHITENESS}

O white, white, white.

White city where women carry bread and vegetables,

women born under the signs of the ever-gyrating zodiacs.

The jaws of fountains spout water in the green sun as in the days past

of nuptials, of strolls in the cold aurora from one outskirt to another.

Buckles from schoolboys' belts somewhere in the dense earth,

bunkers and sarcophagi bound with blackberry ropes.

Revelations of touch, again and again new beginnings,

no knowledge, no memory ever accepted.

A faltering passerby, I walk through a street market after

the loss of speech. The candlesticks in the conquerors' tents overflow with wax,

anger has left me and on my tongue the sourness of winter apples.

Two Gypsy women rising from the ashes beat a little drum and dance for immortal men.

In a sky inhabited or empty (no one cares) just pigeons and echoes.

Loud is my lament, for I believed despair could last and love could last.

In the white city which does not demand, does not know, does not name, but which was and which will be.

BIEL

O białe, białe, białe. Białe miasto, którym niosą chleb i warzywa kobiety urodzone pod znakami wracających moich zodiaków.

Paszcze w zielonym słońcu bluzgają wodą jak w dni dalekich zaślubin, marszów o chłodzie aurory z krańca na kraniec.

Klamry od szkolnych pasków gdziekolwiek w gęstej ziemi, sznurem ożyn przepasane bunkry i sarkofagi.

Objawienia dotyku od początku, nie przyjęta żadna wiedza I żadna pamięć.

Chwiejny przechodzień, idę przez targ uliczny po utracie mowy.

Świeczniki w namiotach zdobywców zalał wosk, opuścił mnie gniew i na języku mam cierpkość zimowej renety.

Dwie Cyganki wstające z popiołu biją w bębenek i tańczą dla nieśmiertelnych ludzi.

Echa, gołębie w zamieszkanym albo pustym, nikt nie troszczy się, niebie. 
Wielki mój lament, bo myślałem, że może trwać rozpacz i że może trwać miłość.

W białym mieście, które nie żąda, nie zna, nie nazywa, a było i będzie.

Paris, $1966^{1}$

In the case of this poem, my first reading experience is the experience of the nebular incapacity of speech, which eludes and leaves no trace in the form of assimilated meaning, which could be expressed by means of words. In any case, the trace (meaning) which is left is negligible, less intense than the flow of escaping words and phrases. Of course, I know poems (including those by the same author) which in the past (or even now) have caused me more difficulty. But Miłosz's Whiteness includes darkness within.

Of course, I am not forgetting that the poem was supplied with a short self-commentary, which I quote in its entirety:

E.C.: The poem Whiteness has a separate title yet in terms of style it could just as well be part of the With Trumpets and Zithers series.

C.M.: Of course. Someone wrote that this poem describes a city of death. Because it brims with white. I will provide you with a specific key. Georges Pompidou had, it seems, the idea of whitewashing Paris, washing out the buildings. The white city in this poem is Paris. In general, France is very much present in my poetry.

E.C.: "A faltering passerby, I walk through a street market after the loss of speech"...

C.M.: This is because I keep saying in my poems over and over again that nothing can be said, that one is actually losing speech. That is why. I tried to speak about what happened in the $20^{\text {th }}$ century and I failed invariably. I wanted to give names to so much and I could not. At the end, the poem naturally reminds us of some love. ${ }^{2}$

The point is that the poem has a property that is worth considering: it evades the interpretation formulated by its author. Between the poet's gloss and the intra-textual "action" there is some sort of rupture, incongruity. The text, I think, works reliably to make its central figure, the "white city." semantically flickering, unobvious and enigmatic. The direct explications of

\footnotetext{
${ }^{1}$ Biel, in: Wiersze, vol. III (Kraków: Znak, 2003). "Whiteness", in: New and Collected Poems. 1931-2001, transl. Robert Hass (New York: HarperCollins Publishers, 2003), 235.

${ }^{2}$ Ewa Czarnecka [Renata Gorczyńska], Podróżny świata. Rozmowy z Czestawem Miłoszem. Komentarze (Kraków: Wydawnictwo Literackie, 1992), 154.
} 
this figure, both negative (it does not demand and does not name) and positive (it will and has been), raise doubts: is this a poem about an ordinary city and ordinary whiteness, or is it really about a realistic epithet and an obvious designate? The author, on the other hand, issues a simple statement: The "white city" is Paris. How to reconcile this clarity of references, declared in the self-commentary, with the effect of non-transparency created in the poem?

A common-sense reminder immediately follows: it is hard to assume that the author's laconic commentary formulated en passant, in an interview, will reveal the full intentio auctoris and elucidate the entire self-consciousness of the text's author. The statement "the white city is Paris" may be a mental shortcut, a partial truth, or a conscious symplification. The existence of the author's gloss does not, therefore, solve my problems with grasping and naming what is legible and meaningful in the written record. I have to look for other points of entry into the text, think about the location of the Archimedean points of interpretation, which helps to set in motion the reading procedures. I could use some leaven to begin with, to use the term zaczat coined by Przyboś. I need the "concrete key" offered to Gorczyńska by Miłosz, the whiteness of Paris, which is no doubt of paramount import and significance, yet I do not think that-and the poet did not claim this in the first place-that this is the best possible key. Even if I assume that the "white city" is the capital of France, there remains one "key" circumstance: the "white city" is not the most elementary, first motif of this poem. It emerges in this poem, performs on an intra-textual scene, appears as the last element of a row, which begins with the title of the poem: "WhitenessO white, white, white. White city where..."

I would like to start the interpretation by reflecting on this sequence of words.

First off, there is a motif with the least degree of concreteness. It is not the "white of something" (of any object), nor "some whiteness" (with specific characteristics), but "simply white," adjective-free, free in general, neither an attribute nor fortified with attributes. Such "whiteness" has no specific symbolic value - out of many potential meanings of white colour, noted by the Dictionary of Symbols, each meaning can (or cannot) refer to it equally well. The movement towards some kind of definition, entanglement in the concrete, starts only with the second element— "Oh white, white, white." The adjective "white" gives rise to "whiteness," which can be used as a description of a feature of some (yet unspeakable) object. A triple repetition of 
the adjective "white" can be associated with a small incantation, a spell that is supposed to have some effect in reality ("Three times will the liars have conquered before the great truth appears alive"...). Or else, it can be linked to the behavior of a person trying to recall a forgotten term composed of a number of words. One way or another, the repetition can be interpreted as a signal of difficulty in retrieving things by means of words. The "O" particle, on the other hand, acts as an imprecise, approximate exponent of the relationship between the speaking "I" and "something white." "White" is what is spoken to, with what one wants to establish some kind of contact (the key of the apostrophe remains undefined: admiration? complaint? surprise? fear?). Finally, the attribute of "whiteness," evoked from the original, adjectiveless "white," finds its object-the formula "white city" emerges, followed immediately by the word "where," opening the space for further additions and names.

Let us note: this poem behaves as if it tried to define itself in its speech. If someone prefers more skeptical and distanced judgments, I can say otherwise: this poem behaves as if it wanted to demonstrate that it is constantly looking for its own definition. Similarly, the subject of the poem presents itself as looking for a name for something that it considers important (if it wants to talk about it), but also difficult to verbalize (if it requires several approaches, attempts, modifications). "Whiteness," "O white, white, white," finally a "white city" - each utterance signals the activity of the subject trying to communicate something (itself? the listening "you"? whiteness?). The final formula "a white city where..." does not in the least provide a definitive solution to the difficulty of expression but actually opens up a new avenue of pursuits. This is confirmed by the further part of the poem: the dark exemplifications of the metaphor of the "white city", the strange use of language that resembles the use of some cipher ("The jaws of fountains spout water in the green sun as in the days past, of nuptials") and the self-definitions of the subject which expose its lack of certainty ("a faltering passerby") and speech impairment ("after the loss of speech").

What is the poem Whiteness about actually? What does it try to say in this strange, uncertain and tiring speech? After all, it is not enough to state that the poem speaks of whitened, distilled Paris, just as it is not enough to state that it shows the impossibility of self-expression. I think it is easier to answer this question if the pressure of such an interpretation ideal that demands the formulation of an integral, coherent interpretation that captures the global meaning of the work is suspended, even for a moment, at least 
"tactically." Therefore, we will agree to an "insular" or "block" view of the semantics of the poem, based on minor observations. For example, we will adopt the following interpretation key:

\section{a) Dominant I: RETURN, REINTEGRATION, REBIRTH}

"women born under the signs of the ever-gyrating zodiacs," "dni dalekich zaślubin," "strolls in the cold aurora from one outskirt to another," "Two Gypsy women rising from the ashes," "immortal men"

refers to some meeting (encounter, arrangement) between something that was distant earlier, as well as about some rejuvenation and the triumph of life.

\section{b) Dominant II: FRAGMENTARINESS, TRANSITION, DISAPPEARANCE}

"Buckles from schoolboys' belts somewhere in the dense earth," "bunkers and sarcophagi bound with blackberry ropes," "The candlesticks in the conquerors' tents overflow with wax," "I believed despair could last and love could last" [yet it turned out it cannot-M.A.]

refers to some disappearance of the traces of past-bloody, dramatic, significant-events, it talks about the fact that the order of nature takes precedence over the order of history, and finally about the fact that what used to be important, powerful and noble gets forgotten.

c) Dominant III: MELANCHOLY, WEAKNESS, APATHY

"Revelations of touch, again and again," "no knowledge, no memory ever accepted," "faltering passerby," "after the loss of speech," "anger has left me," "a sky inhabited or empty (no one cares)"

refers to some state of mind involving a spiritual and intellectual "frigidity," profound resignation, impossibility of action and of expression.

Of course, the above division-starting from the principle of separating the units of meaning, called "dominants" (these are certain sets of meaning read from the text), their number, assignment to specific quotations, etc., and so on-is purely arbitrary. Surely, it could look different, but it does meet its purpose the way it looks now. First of all, it reflects the reading effort; secondly, it propels forward reflection on the poem and penetrates its meaningful potential; thirdly, the map of the dominant allows us to see Biel 
as a constellation of characteristic topoi of Miłosz's poetry. It is easier to see the numerous lines running from this work towards other poems by Miłosz, those in the City Without a Name series as well as earlier and later ones. Actually, when introduced into a state of interpretative constellation, Whiteness "radiates," emits signals that seek "more potent" works, i.e. better consolidated, crystallized (of course, in my reading, in my perception perspective). ${ }^{3}$

There is a fourth asset of this starred poem $^{4}$ : it demonstrates the degree of the inner complexity of the text. Let us note: some local meanings identified in the text remain in explicit agreement, as if they stimulate and justify one another, while others are in opposition, contradicting one another. No doubt, dominant II (TRANSITION) is naturally inked to dominant III (MELANCHOLY): who has seen overgrown "bunkers and sarcophagi," who knows that the conquerors come and go and are forgotten, just like the fallen, can say about himself that "anger has left" him. Yet there is some tension between dominants I and II. The poem refers to both FRAGMENTARINESS and REINTEGRATION, the motif of buckles in the ground, separated from schoolboys' belts (as well as, something not referred to in the poem, the ones who wore them, i.e. pupils) is set aside the motifs of "ever-gyrating zodiacs," "nuptials," "strolls from one outskirt to another." Looking at the drawn map of arbitrary dominants, one can predict that an attempt to build a comprehensive and coherent interpretation, showing not a dispersed, but a global sense of the poem, will face resistance. If it is created, it will be based on negotiation, a mediation effort undertaken by the interpreter of the poem. For example, it will have to be said: when the poem speaks of universal mortality, destructibility and transitoriness (funeral, vanitative motives), it shows the fate of an individual. When, on the other hand, it speaks of immortality, inexhaustibility of life, resurrection (the motif of Gypsies rising from ashes and dancing "for immortal men"), it illustrates the fate of the community, of the human race, which opens itself forever towards the future, revives and

\footnotetext{
${ }^{3}$ For example, "dominant I" (reintegration) may "push" the poem about whiteness closer to a text from the same poetry volume titled When the Moon, "dominant II" (fragmentariness) brings Whiteness closer to e.g. No More (Nie więcej, from the series King Popiel and Other PoemsKról Popiel i inne wiersze), while "dominant III" (resignation) established a relationship with the poem And the City Stood in Its Brightness (I świecito to miasto) from the Bobo's Metamorphosis (Gucio zaczarowany) series (whose text is actually tied with Whiteness with many more threads).

${ }^{4}$ This is patenently obvious, yet I must admit here that the notion of the "starred text" is a borrowing from Roland Barthes, although I believe I use it in this text rather freely, not necessarily in the meaning adopted by the author of $S / Z$.
} 
knows no end. It will have to be said this way, or somehow differently. In any case, a mediation mission will be necessary.

A structured, concentrating and mediating narrative about the Whiteness poem could, I think, proceed as follows: the work is a hardly legible, difficult, enigmatic message about the state of consciousness of the speaking subject. It seems to be a state of enlightenment, a momentary illumination. In this world, which is thought (?), imagined (?), perceived (?) by the subject, everything has its end, and at the same time nothing ends: people die and fall into the nothingness of oblivion-people live and dance, the world disintegrates and exhausts in its very existence-the world renews itself and reintegrates. The subject, endowed with such a strange sense of the world, confronts pure relativity and pure transitoriness, while at the same time sensing that speech, knowledge and memory are gone; only the senses remain.

So we have two images of the text: the starred text and a focusing one. Both of them are superimposed on each other like transparent filters, visible through one another, disturbing the interpreter's vision with the effect of a doubled image, a doubled perspective. The existence of a starred image constantly casts doubt on the contours of the focusing image, reminding us that they emerged as the result of delicate negotiations with the text. Or maybe it was I who imposed my structuring narration on the poem? I am far from the (somewhat dogmatic) claim that this kind of doubt is indispensable everywhere and always in the interpreter's activity; after all, I know texts which are far from simple or artistically handicapped, which did not arouse similar dilemmas in me. However, Whiteness is something different: I look at the plotted map of the dominants, compare it with the story that was later arranged, and I think of a possible illusion of unknown significance. I wanted to reveal the work of a poem which, through the interplay of dispersed meanings, generates a common sense, but I am not sure to what extent I managed to achieve this, and to what extent I introduced my own rules, external to the text, in order to compose a hypothetical whole.

But I want to make it clear: I think, I am convinced, that the source of the difficulty in formulating a holistic, coherent interpretation is the very formation of the poem, rather than my interpretative drive. The effect of disorientation, confusion, disrupted communicativeness is not a projection of my meta-interpretative views on the work, but an intrinsic and constitutive characteristic of the text, which tries to create an integral, global sense, but at the same time makes it clear that it does so in a way that is not effective enough; it speaks, but at the same time distances itself from its words. I suppose that 
this strange property of the text will gain in clarity by comparison with another poem by the same author, written a dozen or so years later. Let us have a look at the magnificent Return to Krakow in 1880 (Powrót do Krakowa w roku 1880), from the Unattainable Earth (Nieobjęta ziemia) volume:

\section{Return to Krakow in 1880}

So I returned here from the big capitals,

To a town in a narrow valley under the cathedral hill

With royal tombs. To a square under the tower

And the shrill trumpet sounding noon, breaking

Its note in half because the Tartar arrow

Has once again struck the trumpeter.

And pigeons. And the garish kerchiefs of women selling flowers.

And groups chattering under the Gothic portico of the church.

My trucks of books arived, this time for good.

What I know of my laborious life: it was lived.

Faces are paler in memory than on daguerrotypes.

I don't need to write memos and letters every morning.

Others will take over, always with the same hope,

The one we know is senseless, and devote our lives to.

My country will remain what it is, the backyard of empires,

Nursing its humilation with provincial daydreams.

I leave for a morning walk tapping with my cane:

The places of old people are taken by new old people

And where the girls once strolled in their rustling skirts,

New ones are strolling, proud of their beauty.

And children trundle hoops for more than half a century.

In a basement a cobbler looks up from his bench,

A hunchback passes by with his inner lament,

Then a fashionable lady, a fat image of the deadly sins.

So the Earth endures, in every petty matter

And in the lives of men, irreversible.

And it seems a relief. To win? To lose?

What for, if the world will forget us anyway.

Tak więc wróciłem tutaj z wielkich stolic,

Do miasteczka w kotlinie pod wzgórzem katedry

Z grobami królów. Na rynek pod wieżą,

Z której przenikliwy głos trąbki obwieszcza południe,

Urywając, bo znów trębacza przebija tatarska strzała.

I gołębie. I jaskrawe chusty kobiet sprzedających kwiaty,

I gromadki w rozmowie pod gotyckim portalem kościoła.

Przybyły moje kufry z książkami, tym razem na zawsze.

O pracowitym życiu wiem tylko, że było,

Twarze są bledsze w pamięci niż na dagerotypach.

Nie muszę już rano zasiadać do listów i memorandów, 
Bo zrobią to za mnie inni, zawsze z tą samą nadzieją, O której wie się, że na nic, choć jej poświęca się życie. Mój kraj tak już zostanie, boczne podwórze imperiów, Prowincjonalnym rojeniem ratujące się od poniżeń. Stukając laską, wyruszam na poranny spacer:

Na miejscu starych ludzi są znów starzy ludzie, A tam gdzie szły dziewczęta z szelestami spódnic, Inne idą tak samo, dumne $\mathrm{z}$ urody.

I dzieci toczą obręcze od z górą pół wieku.

Szewc w suterynie podnosi głowę znad pracy,

Mija mnie garbus ze swoim wewnętrznym lamentem

I dama, tłusty obraz siedmiu grzechów głównych.

Czyli trwa ziemia, każdą drobną sprawą

I żywotami nie do odwrócenia.

A dla mnie z tego ulga. Wygrywać? Przegrywać?

Po co, jeżeli o nas i tak świat zapomni. ${ }^{5}$

It would be indeed easy to make a precise and comprehensive list of "dominants," or principal "mental motifs" shared by Whiteness and Return to Krakow in 1880. The similarities between the poems are clear and advanced. In a nutshell: in both texts, the thought of the city is intertwined with the idea of the irreversible passing of individuals and the coexistence of timeless roles, situations, models. Both poems speak of forgetting, disappearing, blurring of the individual and of the constant renewal and reactivation of the universal. But speaking of (almost) the same, they do so in two diametrically different ways, as if they were ruled by two different philosophies of speaking.

In the poem Return to Krakow in 1880, the speaking subject is someone who shares their experience and understanding of the world in a discursive, argumentative and logical way. It is someone for whom their own speech is fully rational and transparent. The poem Whiteness allows us to hear the voice of the "I" which chooses indirect expression, more evocative, graphic, encoded, and problematic for the speaking persona himself. In Return..., the poem whose first word is "So," knowledge about the inevitable intertwining of transition and continuity is presented as a conclusion, a destination of a mental process. In Whiteness, begun with the incantation "O white, white, white," this knowledge seems rather an object of profound, dazzling and condensed illumination. In Return..., the words are spoken as if they actually

\footnotetext{
${ }^{5}$ Czesław MiŁosz, Powrót do Krakowa w roku 1880, in: IDEM, Wiersze, vol. IV (Kraków, Znak, 2004); "Return to Krakow in 1880", in: New and Collected Poems. 1931-2001 (New York: HarperCollins Publishers, 2003), 427.
} 
named and grasped the world given to simultaneous transition and persistence: "The places of old people are taken by new old people / And where the girls once strolled in their rustling skirts, / New ones are strolling, proud of their beauty." In Whiteness the words that demonstrate the transition and persistence seem to be spoken "instead," "in lieu of" something even more primordial and original, which cannot be expressed more precisely, more effectively and clearly. Here "whiteness" tends towards "something like whiteness," "white" seeks "as if white," "a white city" seems to be indicating something which is "as if a white city."

If I were to express this opposition of Whiteness and Return... in more "technical" terms or categories, I would say that the later poem leans towards direct expression, while the earlier one towards the poetics of implication, continuing the experience of Miłosz's symbolism from Three Winters. Therefore, we must not overestimate the analogies between the representations of the city in both poems. The city in Whiteness is not, cannot be Paris much as the city from the Return... poem is no Krakow. Let us hear the two excerpts once again:

[...] To a town in a narrow valley under the cathedral hill With royal tombs. To a square under the tower

And the shrill trumpet sounding noon.

[...] White city where women carry bread and vegetables, women born under the signs of the ever-gyrating zodiacs.

The jaws of fountains spout water in the green sun as in the days past, of nuptials, of strolls in the cold aurora from one outskirt to another.

In the former image, references to Krakow are particularly intense, as in other texts by Miłosz on this city, e.g. in Beautiful Times from A Treatise on Poetry. Meanwhile, in the second image the "urbanity" has been diluted, the landscape of the city is here as if blurred in the element of some symbolic and archetypical imagery; it is unreal. Perhaps the easiest way to define it is to say as follows: Return... is a poem about Krakow at the end of the nineteenth century, which becomes a metaphor for the simultaneity of ending and endurance. Whiteness, on the other hand, is a poem about the state of mind, experiencing illumination on the subject of passing and perseverance; this state is expressed by the vision of a "white city," in which one can

\footnotetext{
6 "Instead" is a word raised to the level of defining Miłosz's writing by Marek Zaleski, see the excellent essay "Zamiast" [Instead], in: IDEM, Zamiast. O twórczości Czesława Miłosza (Kraków: Wydawnictwo Literackie, 2005).
} 
recognize the "dissolved" substance of Paris. However, this recognition is made possible by interventions that are external to the text: paratextual $^{7}$ information about the date and place of the poem's origin-Paris, 1966and the author's explication of a much later date. ${ }^{8}$

Therefore: interpretation may be effected as an attempt to feel at home in the text. Now, having written down a few reflections on Whiteness, it is easier to justify the term used. Being at home with the poem, arriving at some ideal centre of the text, the centre of speech, is the poets' dream:

To find my home in one sentence, concise, as if hammered in metal. Not to enchant anybody. Not to earn a lasting name in posterity. An unnamed need for order, for rhythm, for form, which three words are opposed to chaos and nothingness.

Zamieszkać w zdaniu, które byłoby jak wykute z metalu. Skąd takie pragnienie? Nie żeby kogoś zachwycić. Nie żeby utrwalić imię w pamięci potomnych. Nienazwana potrzeba ładu, rytmu, formy, które to trzy słowa obracamy przeciwko chaosowi i nicości. ${ }^{9}$

Certainly, not all poets can relate to such a dream. A case in point is Ryszard Krynicki who poses the polemical question: "Who will be consoled / by a sentence hammered in metal?" ${ }^{10}$ However, for Czesław Miłosz, the author of the above epigraph, "to find home in one sentence" is the formula that defines the author's myth of perfect and absolute expression. The metaphor of interpretation as being at home in what one interprets expresses

\footnotetext{
${ }^{7}$ On Genette's concept of paratexts see D. SZEJNERT, "Osoba w paratekstach", in: Osoba w literaturze i komunikacji literackiej, ed. Edward Balcerzan, Włodzimierz Bolecki (Warszawa: Instytut Badań Literackich, 2000).

${ }^{8}$ In her eminent study on "Miłosz's geography," Tarnowska places Whiteness in a series of the author's statements about Paris. From the position I take in this essay, I can only add: I agree with the addition of one reservation-Paris is textualised in Whiteness in a completely different way than in the other "Parisian" texts by the poet, indicated and discussed by Tarnowska. See Beata TARnowsKa, Geografia poetycka w powojennej twórczości Czesława Miłosza (Olsztyn: Wyższa Szkoła Pedagogiczna, 1996).

${ }^{9}$ Czesław MıŁosz, Zamieszkać w zdaniu, in: IDEM, Wiersze, in: New and Collected Poems. 1931-2001 (New York: HarperCollins Publishers, 2003), 452.

${ }^{10}$ Ryszard KRYNICKI, Kogo pocieszy?, in: IDEM, Wiersze wybrane (Kraków: Wydawnictwo a5, 2009).
} 
a parallel reader's myth of a perfect reading. It derives a bit from the style of classical metaphors of $20^{\text {th }}$-century hermeneutics (with its privileged motifs of "home" and "flat"), and partly from the commonly accepted, universal metaphorical code, defining the act of interpretation in spatial, internal and external terms. After all, one often speaks of "entrances into the text," "penetrations" and "immersions," "shallow" or "deep" readings.

But this metaphor, like any attempt to talk about values, is exposed to the danger of trivialization, of slipping into literary "theatrics," empty words and false pathos of names. Only one thing can defend it from such a fatean attempt to rethink its possible meanings.

To "settle in" means to perform work that will make me feel at home in a place away from home. This is how the literary text interpreter can understand his work and his effort. I read-and try to understand my lack of understanding, its nature and cause. I read-and I strive to make the text starred. I read-and try to define possible orders according to which scattered meanings could form constellations. I read-and I do not believe these orders, I criticize their system of rules, their grammar. I read-and I follow the lines leading from the text being interpreted to other texts (or extratexts). I read - and I think about the relationship between the adopted mode of reading and the theories of interpretation known to me and their, usually extensive, philosophical justifications. I read-and.... all the actions, taken once, bind me with the text and bind the text with me. The actions somehow make the text mine.

Taken once! And what will happen if I repeat, check, correct, undo, disturb and amplify these actions. What if I reread the book and find my trace, recalling my being here before, at this stanza, at this verse, at this group of consonants, trying to do something with them. It is not only the "poet who lives by repetition"; this applies to the interpreter, too. To interpret is to return to the "I" existing in relation to the text. My presences somehow add up. There is more and more text in me (in my memory, in my thoughts about literature, or maybe not only about literature) and more and more of me through the text. The pursuit of this doubling of "more and more" is what I call accommodation in the text. Being at home in this sense is a potentially infinite process, assuming a constant repetition of contact and a deepening of the relationship with the poet's word. There is no limit to "being at home"; there is no moment to say: this text has already become my text, I don't have to do anything more for its being "mine." Being at home is an unattainable horizon of reading aspiration. 
I hope that my story and that of Whiteness, the story told in brief in this essay, is also a story of this "being at home" (or rather of begun and unfinished "becoming at home"). When I look back on my path of thinking about the poem, I can clearly see that the key to the interpretation vision of the text was paying heed to my own lack of understanding. My own lack of comprehension, recognized, reflected on and analyzed is a value which should not be easily discarded. I could, of course, subordinate the reading to the authorial commentary, I could accept the statement that the "white city is Paris" as my first elementary knowledge of the text, and with this assumption to start pursuing the meanings. But I don't think I would be going in the direction of interpretation as being at home, then. The starting point would be a statement which I had not worked out myself, which came to me from outside, from outside the space of encounter with the text. Meanwhile, my first contact with the work was precisely a misunderstanding and, as it turned out, it was not at all a bad, shallow and superficial contact. The longer the reading lasted, the more it became clear that in the case of a poem such as Whiteness, the sense of nebularity of the meanings discovered does not separate one from the text, but, on the contrary, brings one closer to it. It does not hinder but in fact facilitates the contact between the reader and what is being read. It corresponds to the style of the linguistic behavior of the subject, which does not feel too secure in the words spoken. The subject seeks for a solid ground in language, seeks a place where it could stand and understand itself and what it thinks about. I seek in the poem interpretative supports, or places which help to define and name better the meaning of the text and one's reactions to the text. Our pursuits differ, though, and take place at different levels of reality, yet it satisfies me to think that they are still akin to each other. When I specify and call arbitrary dominants of meaning, when I then think about the possibility of arranging them in one coherent narrative, I am aware that I still miss the real movement of senses, which in the text is always somehow different from that in my story. But, after all, a similar law of inevitable distance governs the poem itself, constantly eluding its imperfectly captured, incomprehensible, and imperfectly revealed object.

The metaphor of interpretation as being at home in the text may create some misunderstanding and suggest that the interpreter strives for a state in which the text loses its ability to surprise, is already fully predictable: you know what is clear and what is dark in it, you know what can be asked about it, and you know which questions will be answered. In order to prevent such misunderstandings, however, it is enough to add: if being at home in the text 
were to be the image of interpretive success, it should look like the one in the "homely" poems by Miron Białoszewski. The home space there is never completely domesticated. The inhabitant retains the ability not to get used to the surrounding objects, while these objects on their part do not lose the ability to "be as if - constantly_anew," without falling into the rut of a habitual way of existence. The same applies to the interpretation of literature. The sense of establishment in the text is certainly not homogeneous and consists of many aspects. To feel at home in a poem is to delve into its language, but also to make a work an observation point, a place from which one can see all the work of a given author and a network of its internal connections. It means moreveor to find in the text traces leading to the author of the text, to extra-textual worlds, and so on and so long. Yet, if being at home in the text were to be real, it must include one more element. I will speak about it in the shortest possible way: interpretive domestication in the text manifests itself in a state of increased sensitivity to language and the word. This state is the opposite of habit, which blunts the sense of feeling and makes the reader's attention slide down the text as if on a smooth surface, losing the individual, unique stories of words. If I read for an umpteenth time Whiteness by Czesław Miłosz, I recognize that in the second verse there is an alliance of two words, not found in any other poem by the same author, unsettling precisely because of its unqueness: "a green sun." I do not have an interpretative idea that would define the meaning conveyed by this place of the text. Maybe one day I will formulate such an idea, but it is not the most important one. It is important that a part of my Whiteness experience remains a sensitivity to otherness, uniqueness, a peculiar "loneliness" of this relationship of two words, reminding us of different bizarre suns in Miłosz's poetry (first and foremost the black sun), ${ }^{11}$ which cannot however be defined by a common, solar denominator.

By way of conclusion: I fully realize that this essay leaves many things unsaid. This applies both to the poem itself (there are still a vast number of questions one may pose with respect to Whiteness), and to the metaphor of "being at home in the text." As any other metaphor, it draws behind it a tail of associations calling for reflection and testing. The word has become flesh, though: being at home in the text is ex definition an unfinished process. Therefore, thinking about it will not be difintitive, either. The interrupted

\footnotetext{
${ }^{11}$ See Marian STAla, "Od czarnego słońca do ciemnego świecidła," in: IDEM, Chwile pewności: 20 szkiców o poezji i krytyce (Kraków: Znak, 1991).
} 
continuum may be returned to (although, as is true of any return, the one who returns is different and comes back to a different place). In the meantime, an ideal and indefintive conclusion of the text may be the recognition of the moment of sensitivity to an irreducible, lexical and phraseological selfness of the interpreted poem: there is a sun shining over the "white city," conjured up by the poet's power (or lack of it?) from the depth of whiteness. This sun is green.

\title{
BIBLIOGRAPHY
}

Barthes, Roland. S/Z. Translated by Richard Miller. New York: Hill and Wang, 1974.

Czarnecka, Ewa, [Gorczyńska, Renata]. Podróżny świata. Rozmowy z Czesławem Miłoszem. Komentarze. Kraków: Wydawnictwo Literackie, 1992.

KRYNICKI, Ryszard. Kogo pocieszy? In IDEM. Wiersze wybrane. Kraków: Wydawnictwo a5, 2009.

MıŁosz, Czesław. Biel. In IDEM. Wiersze, vol. III. Kraków: Znak, 2003.

MıŁosz, Czesław. Powrót do Krakowa w roku 1880. In IDEM. Wiersze, vol. IV. Kraków: Znak, 2004.

MıŁosz, Czesław. (Zamieszkać w zdaniu). In IDEM. Wiersze, vol. IV. Kraków: Znak, 2004.

MıŁosz, Czesław. New and Collected Poems. 1931-2001. Translated by Robert Hass. New York: HarperCollins Publishers, 2003.

Stala, Marian. "Od czarnego słońca do ciemnego świecidła.” In IDEM. Chwile pewności: 20 szkiców o poezji i krytyce. Kraków: Znak, 1991.

SZEJNERT, Danuta. "Osoba w paratekstach." In Osoba w literaturze i komunikacji literackiej, edited by Edward Balcerzan, Włodzimierz Bolecki. Warszawa: Instytut Badań Literackich, 2000.

TARnowska, Beata. Geografia poetycka w powojennej twórczości Czesława Miłosza. Olsztyn: Wyższa Szkoła Pedagogiczna, 1996.

ZALESKI, Marek. Zamiast. O twórczości Czesława Miłosza. Kraków: Wydawnictwo Literackie, 2005.

\author{
INTERPRETATION AS FEELING SETTLED. \\ A FEW THOUGHTS ABOUT READING (POEMS)
}

\section{Summary}

The article is a suggestion for an interpretation of Czesław Miłosz's poem Biel (Whiteness) (from the volume Miasto bez imienia (City Without a Name). The accepted methodology of interpretation tries to find and define the zone of mediation between the ideal of comprehensive reading, striving after integrating and structuralizing the global meaning of the work, and the suggestions coming from post-structuralist philosophy of reading texts. The author's own interpretation of the poem has been taken into consideration; a comparative reading of Biel has been suggested as well as of a Miłosz's later poem Powrót do Krakowa w roku 1880 (Return to Krakow in 1880). This comparison is supposed to serve showing different strategies of creating texts and meanings used by the author of Nieobjęta ziemia (Unattainable Earth). 
At the same time, in the background, a commentary to Miłosz's poem becomes an opportunity to construct a meta-interpretative reflection. Looking at his own reading the author formulates remarks concerning the process of reading and comprehending, he introduces and analyzes the metaphor of "interpretation as feeling settled."

Key words: interpretation, meaning, Czesław Miłosz’s poetry.

\section{Translated by Marcin Turski}

The preparation of the English version of Roczniki Humanistyczne (Annals of Arts) and its publication in electronic databases was financed under contract no. 836/P-DUN/2018 from the resources of the Minister of Science and Higher Education for the popularization of science. 